\title{
A STUDY ON THE EFFECT OF CEMENT DUST POLLUTION ON CERTAIN PHYSICAL AND BIOLOGICAL PARAMETERS OF BRASSICA CAMPESTRIS PLANT
}

\author{
Rajendra N Deshmukh, **Punita Tiwari , and Piyush kumar Sharma \\ Botany Department, Shivaji Science college, Nagpur Shivaji Science College, \\ Congress Nagar Nagpur \\ Corresponding author: punitatiwari9@gmail.com
}

\begin{abstract}
Air pollution has a various effect on much metabolic process in plants such as photosynthetic activities, mitochondrial respiration and stomatal structure of plants. This study is carried out in Congress Nagar area of Nagpur city. Construction work particularly construction of metro bridges in different parts of Nagpur city, may lead to increase in the amount of cement dust in environment. These act as the sources of dust and other particles in and around the living place. To know about the extent of dust pollution, a common plant Brassica campestris was found to be one of the plants which are higher in number. The chlorophyll $\mathrm{a}$, Chlorophyll b, total chlorophyll, and carotenoid content of the leaves have found to decrease in the leaves of the plant grown in areas exposed to dust when compared with unpolluted plants. Similarly the other components such as calcium, sodium, manganese magnesium, zinc got increased in the affected plant Brassica campestris. Certain parameters such as alkaloids and flavonoids, have got decreased in its quantity in case of affected plant Brassica campestris. It is clear that the cement dust particles affect certain biochemical properties of plants.
\end{abstract}

Keywords: Cement dust, chlorophyll, Brassica campestris, carotenoid.

\section{INTRODUCTION:}

Air pollution has a diverse effect on much metabolic process in plants such as photosynthetic activities, mitochondrial respiration and stomatal structure of plants (Miller et al., 1973). Industries as well as construction work are emitting toxic substances which adversely affect man's food supply by polluting nearby growing plants. Construction activities like construction of bridges are responsible for altering the ecosystem. The Cement dust plays a vital role in the imbalances of the environment and produces air pollution hazards. Physiological abnormalities such as reduced growth are due to the cumulative effects of the causal factors on the physiological processes requiring for plant growth and its development. Increased level of air pollution has been shown to affect functions of stomata, leaves and root of young beech
(Taylor and Davies, 1990). One of the most recent studies of these stresses was a dust accumulation, which leads to formation of severe damage in the photosynthetic apparatus (Santosh \& Tripati,2008).

Increasing amount of cement dust causes in visible abnormalities like progressive decline in physiological process such as photosynthetic activity and respiration rate. Hence, the present investigation was undertaken to study the effect of structural and functional aspects of selected crop plant Brassica campestris in the field condition under natural exposure to Cement dust pollution. Number of literatures showed that there is a direct relation between cement dust deposition and physiological process in plants. Since the studying area is affected with heavy cement dust which deposits on the plants and producing a significant adverse effect. A periodical study was carried 
out to study the effect of cement dust pollution on the growth of selected Brassica campestris plant.

\section{MATERIALS AND METHODS:}

The chlorophyll is the important components for photosynthesis, and found in chloroplasts photosynthetic plant tissues. They are readily extracted in organic solvents such as acetone and ether.

Chemically, each chlorophyll molecule contains a tetrapyrol nucleus with a chelated magnesium atom at the centre and a long chain hydrocarbon side chain attached through a carboxylic acid group.

\section{Estimation of Chlorophyll}

The plant Brassica campestris selected for field study. The plants samples were collected from $0.5,1.0$ and $2.0 \mathrm{~km}$ distance from construction area. Control site was selected $16 \mathrm{~km}$ away from construction site. The plant samples were collected from both control and polluted site. PIAEE (2013) method was used to estimate the chlorophyll content of the plant. The photo synthetic pigment were extracted from leaves in $80 \%$ acetone and centrifuged at 3000 RPM for 15 minutes to remove the debris. The volume of clear extract was made up to $100 \mathrm{ml}$ by the addition of $80 \%$ acetone and its absorbance at 645 and $663 \mathrm{~nm}$ measured with a spectrophotometer.

Chlorophyll a and $\mathrm{b}$ were determined by using the formulae given by Arnon, 1949. The total Chlorophyll content was obtained by addition both the chlorophyll $a$ and $b$ values.

Some calculations were listed as follows: mg of chlorophyll a /g = 12.7 (A663) - 2.69

$(\mathrm{A} 645) \times 1000 \times \mathrm{W} / \mathrm{V}$

mg of chlorophyll b /g = 22.9 (A645) -4.68

$(\mathrm{A} 663) \times 1000 \times \mathrm{W} / \mathrm{V}$

and

$\mathrm{mg}$ of chlorophyll/g $=20.2(\mathrm{~A} 645)+8.02$

$(\mathrm{A} 663) \times 1000 \times \mathrm{W} / \mathrm{V}$

Where

$\mathrm{A}=$ Absorbance at specific wavelengths,

$\mathrm{V}=$ Final volume of chlorophyll in $80 \%$ acetone, and

$\mathrm{W}=$ Fresh weight of tissue extracted. were done as per CLSI guidelines.

\section{RESULTS AND DISCUSSION:}

Affected area is Brassica campestris. The chlorophyll a, chlorophyll b, total chlorophyll and carotenoid levels of the sampled plants were calculated and the results are tabulated in (table - 1). The amount of total chlorophyll in affected leaves was $4.991 \mathrm{mg} / \mathrm{g}$ and that of control leaves was $5.422 \mathrm{mg} / \mathrm{g}$.

Similarly in the various biochemical components of the control and affected leaves of Brassica campestris was tabulated ( Table2). A marked increase is seen in the content of total calcium, sodium, zinc \& copper content because dust particles contains several nutrients including $\mathrm{S}, \mathrm{B}, \mathrm{Ca}, \mathrm{Mg}, \mathrm{Fe}$, $\mathrm{Cu}, \mathrm{Zn}, \mathrm{Mn}, \mathrm{P}$, which are crucial for plant growth.

A considerable loss in total chlorophyll in the leaves of plants exposed in severe air pollution supports the argument that the chloroplast is the primary site of attack by air pollutants which make their entrance into the tissues through the stomata and cause partial denaturation of the chloroplast and 
decreases pigment content in the cells of polluted leaves.

The reduced photosynthetic potential of dusted plants as affected by decreased absorption of light (Peirce, 1910; Czaja, 1962), internal damage to leaf tissue (Rehman and Mohamed, 2012; Sadhana et al. 2013), interruption in CO2 gas exchange (Czaja, 1962; Darley, 1966) and reduced photo synthetic area.

Similarly certain parameters such as alkaloids and flavonoids have got decreased in its quantity in case of affected plants. Thus the effect of cement dust on one of the commonest plant Brassica campestris has been studied. It is clear from the observation that the cement dust particles affects certain biochemical components of Brassica.

The phytochemical compounds were quantitatively estimated in various species of Brassica include phenolics, flavonoids, ascorbic acid, glucosinolates, carotenoids, and tocopherols. Table 2 present the phytochemical content (total phenolic content of various extracts of some parts of Brassica campestris. The organic extracts of the various parts of Brassica campestris plants have been found to contain the considerable amounts of phenolic compounds, flavonoids, carotenoids, ascorbic acid, and tocopherols which indicates the suitability of Brassica plants for pharmaceutical applications

\section{REFERNCES :}

Chakraborty, SP., Pramanik, P., and Roy, S. Chandrasekaran, G.E and
Ramkumar.1994 Indian, Geographical Journal.,69 (1) :pp- 40- 59.

Chandrasekaran, G.E, Ravichandran. C, Mani Bhusan Singh, K.K. Ind. J.Environ. Prot. 1915, 16(5): pp 356358.

Czaja AT. Angewandte Botanik, 1962, 40: 106-120

Edwin chandrasekaran, G.E. J. Ecotoxicol. Environ. Monit. 1995,5(3): pp -203 -

206.

Indian Pharmacopoeia, Controller of Publications, New Delhi, India. 1966, 2: 230-232

Peirce GJ. Plant World, 1910, 13: 283-288

Proceedings of the International Academy of Ecology and Environmental Sciences (PIAEE), 2013, 3(4): 288- 295

Rehman AM, Mohamed MI. Egyptian Academic Journal Of Biological Sciences, 2012, 3(1): 1-11

Thangarasu. S. 2002 Comparative field investigations on structural and functional aspects of few cropsunder unnatural exposure to cement kiln dust. Ph. D Thesis (Bharathidasan University,).

Darley EF. Journal of the Air Pollution Control Association, 1966, 16: 145150

Rao DN. 1971Study of the air pollution problem due to coal unloading in Varanasi, India. Proceedings of the 2nd Inter Clean Air Congress, Engly HM, Berry WT, (Ed.), 273-276, Academic Press, New York, USA

Devarajan L, Rajanan R, Ramanathan R, Oblisam G. 1994. Performance of field crops under distillery effluent irrigation. Kisan World. (21): 48-50.

Tiwari S. 1991. Studies of Air Pollution Tolerance Indices of some planted trees in urban areas of Bhopal with reference to Eco-planning of Industrial areas. Ph .D. Thesis, Barkatullah University, Bhopal, India 
Table -1. Chlorophyll Estimation of Brassica campestris in the study area

\begin{tabular}{|l|l|l|l|}
\hline samples & $\begin{array}{l}\text { Chlorophyll a } \\
(\mathrm{mg} / \mathrm{g})\end{array}$ & $\begin{array}{l}\text { Chlorophyll b } \\
(\mathrm{mg} / \mathrm{g})\end{array}$ & $\begin{array}{l}\text { Total Chlorophyll } \\
(\mathrm{mg} / \mathrm{g})\end{array}$ \\
\hline Control leaf & $1.880 \pm 0.020$ & $3.542 \pm 0.150$ & $5.422 \pm 0.170$ \\
\hline leaf sample 1 Area $(0.5 \mathrm{~km})$. & $1.726 \pm 0.038$ & $2.862 \pm 0.125$ & $4.588 \pm 0.163$ \\
\hline $\begin{array}{l}\text { leaf sample 2 Area } 1(1.0 \\
\mathrm{km} .)\end{array}$ & $1.511 \pm 0.220$ & $2.686 \pm 0.456$ & $4.197 \pm 0.676$ \\
\hline $\begin{array}{l}\text { leaf sample 3 Area } 1(2.0 \\
\mathrm{km} .)\end{array}$ & $1.311 \pm 0.140$ & $3.680 \pm 0.427$ & $4.991 \pm 0.837$ \\
\hline
\end{tabular}

Table -2. Biochemical analysis of Brassica campestris in the study area

\begin{tabular}{|c|c|c|c|c|}
\hline \multirow{3}{*}{ SI.NO } & \multirow{3}{*}{ Extracting solvent } & \multirow{3}{*}{$\begin{array}{l}\text { Name of the parameter } \\
\text { in } \mathrm{mg} / \mathrm{g} \text { (leaf extract) }\end{array}$} & \multicolumn{2}{|c|}{ SAMPLE DETAILS } \\
\hline & & & \multicolumn{2}{|c|}{ Brassica campestris } \\
\hline & & & affected & Control \\
\hline 1 & $\begin{array}{l}\text { Ethanol, methanol, } \\
\text { acetone }\end{array}$ & $\begin{array}{l}\text { Total phenolic } \\
\text { content }(\mathrm{mg} / \mathrm{g})\end{array}$ & 9.03 & 12.78 \\
\hline 2 & $\begin{array}{l}\text { Ethanol, methanol, } \\
\text { acetone }\end{array}$ & flavonoids & 2.25 & 3.60 \\
\hline 3 & Hexane & Carotenoid (mg/g) & 5.80 & 6.78 \\
\hline 4 & Methanol & glucosinolates (mg/g) & 0.15 & 0.19 \\
\hline
\end{tabular}

